\title{
Metallomics
}

Check for updates

Cite this: Metallomics, 2019, 11,1411

Received 31st May 2019

Accepted 8th July 2019

DOI: 10.1039/c9mt00144a

rsc.li/metallomics

\section{Inorganic arsenic causes intestinal barrier disruption}

\author{
Gabriela M. Chiocchetti, Dinoraz Vélez and Vicenta Devesa (D)*
}

Significance to metallomics

The present study provides novel information regarding the mechanisms of toxicity of inorganic arsenic at the intestinal level. This is the first article that links the inflammatory response caused by these arsenical forms and the impairment of intestinal barrier function, which could lead to an increase permeability of pathogenic microorganisms and toxic compounds, included inorganic arsenic.

\section{Introduction}

Inorganic arsenic (As) is the most toxic form of this metalloid that is found in food and water. The International Agency for Research on Cancer has classified the inorganic form as carcinogenic to humans (group 1A), indicating that inorganic As compounds, including arsenic trioxide, arsenite and arsenate, cause cancer of the lungs, urinary bladder and skin. A positive association has also been observed between exposure to inorganic As compounds and cancer of the kidney, liver and prostate. ${ }^{1}$ Epidemiological studies also show a greater incidence of cardiovascular pathologies, type 2 diabetes and neurobehavioural disorders in child populations. ${ }^{2}$ Studies to evaluate the toxic effect of inorganic As have concentrated on target organs; however, little research has been aimed at determining

Instituto de Agroquimica y Tecnología de Alimentos (IATA-CSIC), Calle Agustín Escardino 7, 46980 - Paterna, Valencia, Spain. E-mail: vdevesa@iata.csic.es; Fax: (+34) 963636 301; Tel: (+34) 963900022 the toxicity at the gastrointestinal level and the mechanisms responsible for it.

The epithelial layer of the gastrointestinal mucosa acts as a barrier with selective permeability, allowing the passage of nutrients, electrolytes and water and at the same time maintaining effective defence against xenobiotics, luminal antigens and enteric flora. ${ }^{3}$ Various in vitro and in vivo studies have shown that the intestinal permeability can be affected by many factors, such as cytokines, pathogens, and toxic substances such as alcohol and some components of the diet. ${ }^{3,4}$ Barrier function impairment is considered a critical determinant in predisposition to presenting inflammatory processes at the intestinal level, such as Crohn's disease, ulcerative colitis and food allergies, and functional disorders of the intestine such as irritable bowel syndrome. ${ }^{5}$ Moreover, it is also associated with the pathogenesis or progression of disorders at other levels, such as IgA nephropathy, ${ }^{6}$ hepatic steatohepatitis ${ }^{7}$ and multiple sclerosis. ${ }^{8}$

In vitro studies have shown that acute exposure to As(III) generates oxidative stress and a pro-inflammatory response in 
intestinal epithelial cells. ${ }^{9-11}$ In addition, Chiocchetti et al. ${ }^{12}$ demonstrated in vitro that continuous exposure (21 days) to $\operatorname{As}(\mathrm{III})\left(\leq 0.075 \mathrm{mg} \mathrm{L}^{-1}\right)$ and $\mathrm{As}(\mathrm{v})\left(\leq 0.75 \mathrm{mg} \mathrm{L}^{-1}\right)$ can generate effects on the ultrastructure and functionality of the epithelial monolayers of the intestine. There is a reduction in the barrier function of the intestinal monolayer, a loss of regenerative capacity and an effect on the processes of proliferation and differentiation. This toxic effect on the epithelial monolayers of the intestine may be due to a condition affecting a series of mechanisms responsible for maintaining intestinal homeostasis, evaluation of which could increase knowledge about the mechanisms of the toxicity of inorganic As. Also, knowledge of the way in which inorganic As acts at this level may provide the basis for a search for strategies aimed at reducing its intestinal toxicity, which, as indicated earlier, may be associated with gastrointestinal and systemic disorders.

The aim of this study is to determine the cellular mechanisms of the toxicity of the inorganic forms of $\mathrm{As}[\mathrm{As}(\mathrm{III})$ and $\mathrm{As}(\mathrm{v})]$ on the epithelial cells of the intestine. For this purpose, two intestinal epithelium cell models were used: non-transformed human colon epithelial cells (NCM460) and epithelial cells from a human colorectal adenocarcinoma (Caco-2), both commonly used in studies of intestinal toxicity.

\section{Methods}

\subsection{Chemicals}

The As(v) standard solution (1000 $\left.\mathrm{mg} \mathrm{L}^{-1}\right)$ was acquired from Merck (Madrid, Spain). The As(III) standard (1000 $\mathrm{mg} \mathrm{L}^{-1}$ ) was prepared by dissolving $1.320 \mathrm{~g}$ of $\mathrm{As}_{2} \mathrm{O}_{3}$ (Riedel de Haën, Seelze, Germany) in $25 \mathrm{~mL}$ of $\mathrm{KOH}$ (Panreac, Barcelona, Spain) at 20\% $(\mathrm{m} / \mathrm{v})$, neutralizing with $20 \% \mathrm{H}_{2} \mathrm{SO}_{4}(\mathrm{v} / \mathrm{v})$ (Merck) and making up to a final volume of $1 \mathrm{~L}$ with $1 \% \mathrm{H}_{2} \mathrm{SO}_{4}(\mathrm{v} / \mathrm{v})$.

\subsection{Cell line culture conditions and As treatments}

The human colon carcinoma Caco- 2 cell line was obtained from the European Collection of Cell Cultures (ECACC; number 86010202, Salisbury, UK) and the non-transformed human colon mucosal epithelial cell line NCM460 was acquired from INCELL Corporation (San Antonio, TX, USA). The cells were maintained in $75 \mathrm{~cm}^{2}$ flasks to which $10 \mathrm{~mL}$ of Dulbecco's Modified Eagle Medium (DMEM) with high glucose $\left(4.5 \mathrm{~g} \mathrm{~L}^{-1}\right)$ and L-glutamine $\left(0.6 \mathrm{~g} \mathrm{~L}^{-1}\right)$ was added. For the Caco-2 cells, DMEM was supplemented with $10 \%(\mathrm{v} / \mathrm{v})$ of fetal bovine serum (FBS), 1\% (v/v) of non-essential amino acids, $1 \mathrm{mM}$ of sodium pyruvate, $10 \mathrm{mM}$ of HEPES $\left(N\right.$-2-hydroxyethylpiperazine- $N^{\prime}-2$ ethanesulfonic acid), $100 \mathrm{U} \mathrm{mL}^{-1}$ of penicillin, $0.1 \mathrm{mg} \mathrm{mL}^{-1}$ of streptomycin and $0.0025 \mathrm{mg} \mathrm{L}^{-1}$ of amphotericin B (DMEMc). For the NCM460 cells, DMEM was supplemented with $10 \%(\mathrm{v} / \mathrm{v})$ of FBS, $100 \mathrm{U} \mathrm{mL}^{-1}$ of penicillin, $0.1 \mathrm{mg} \mathrm{mL}^{-1}$ of streptomycin and $0.0025 \mathrm{mg} \mathrm{L}^{-1}$ of amphotericin B (NCM-DMEMc). All the reagents used in cell maintenance were obtained from HyClone (Fisher Scientific, Madrid, Spain).

The cells were incubated at $37{ }^{\circ} \mathrm{C}$ in an atmosphere with $95 \%$ relative humidity and a $\mathrm{CO}_{2}$ flow of $5 \%$. The medium was changed every 2-3 days. When the cell monolayer reached $80 \%$ confluence, the cells were detached with a solution of trypsin $\left(0.5 \mathrm{~g} \mathrm{~L}^{-1}\right)$ and EDTA (ethylenediaminetetraacetic acid, $0.2 \mathrm{~g} \mathrm{~L}^{-1}$ ) (HyClone). The assays were performed with cultures between passages 5 and 25 .

For As exposure, the cells were grown in DMEMc or NCMDMEMc in well-plates of various dimensions, depending on the assay. Nine-eleven days post-seeding, the cells were treated with As(III) or As(v) prepared in Minimum Essential Medium Eagle with Earle's salts (MEM, HyClone) supplemented with $1 \mathrm{mM}$ of sodium pyruvate, $100 \mathrm{U} \mathrm{mL}^{-1}$ of penicillin, $0.1 \mathrm{mg} \mathrm{mL}^{-1}$ of streptomycin and $0.0025 \mathrm{mg} \mathrm{L}^{-1}$ of amphotericin B (MEMc).

Before the toxicity studies, the effect of inorganic As on the viability of the two types of cells was evaluated in order to work under sublethal conditions. The viability studies were based on the ability of the viable cells to reduce sodium resazurin (7-hydroxy-3H-phenoxazin-3-one-10-oxide sodium salt, Sigma, Madrid, Spain) to resorufin, both measurable by colorimetric methods. ${ }^{13}$ In this study it is considered that sublethal treatments are treatments that do not produce reductions in viability greater than $20 \%$.

The range of concentration selected for the present study was similar to those found in contaminated water (up to $\left.1.3 \mathrm{mg} \mathrm{L}^{-1}\right)^{14,15}$ and food products [dried seaweed (up to $100 \mathrm{mg} \mathrm{kg}{ }^{-1}$ ); ${ }^{16}$ bivalves (up to $5 \mathrm{mg} \mathrm{kg}^{-1}$ ); ${ }^{17}$ and rice from contaminated areas (up to $2 \mathrm{mg} \mathrm{kg}^{-1}$ ) ${ }^{18}$.

\subsection{Pro-inflammatory response}

Cells were seeded at a density of $3 \times 10^{4}$ cells per $\mathrm{cm}^{2}$ in 12 -well plates. Nine days after seeding, the monolayers were exposed for 2, 4 and $24 \mathrm{~h}$ to $\operatorname{As}(\mathrm{III})$ (1 and $3 \mathrm{mg} \mathrm{L}^{-1}$ ) and $\operatorname{As}(\mathrm{v})(5$ and $8 \mathrm{mg} \mathrm{L}^{-1}$ ) prepared in MEMc. When the exposure time ended, the medium was recovered for analysis of the pro-inflammatory cytokines IL-2, IL-6, IL-8 and TNF $\alpha$, using specific ELISA kits [IL-2 Human Instant ELISA ${ }^{\mathrm{TM}}$ Kit (Invitrogen, Fisher Scientific), Human IL-6 Elisa kit (Sigma), Human IL-8/CXCL8 Elisa Kit (Sigma), and TNF alpha Human ELISA Kit (Invitrogen, Fisher Scientific)], following the manufacturers' instructions. The values were normalized per mg of protein determined by the Bradford method (Bio-Rad Protein Assay, Bio-Rad, Hercules, CS, USA).

\subsection{Determination of reactive oxygen and/or nitrogen species}

Cells were seeded at a density of $3 \times 10^{4}$ cells per $\mathrm{cm}^{2}$ in 12 -well plates. Nine days after seeding, the monolayers were exposed for 2, 4 and $24 \mathrm{~h}$ to $\mathrm{As}(\mathrm{III})\left(1\right.$ and $\left.3 \mathrm{mg} \mathrm{L}^{-1}\right)$ and $\mathrm{As}(\mathrm{v})\left(5\right.$ and $\left.8 \mathrm{mg} \mathrm{L}^{-1}\right)$ prepared in MEMc.

After treatment, the cells were washed with phosphate-buffered saline (PBS, Hyclone) and they were incubated for $30 \mathrm{~min}$ at $37{ }^{\circ} \mathrm{C}$ with a solution of $200 \mu \mathrm{L}$ of $100 \mu \mathrm{M} 2^{\prime}, 7^{\prime}$-dihydrochlorofluorescein diacetate (DHCF-DA, Sigma) prepared in PBS. After that time the cells were lysed using $300 \mu \mathrm{L}$ of Triton X-100 $(0.1 \% \mathrm{~m} / \mathrm{v}$ in PBS) (Merck). After sonication (10 $\left.\mathrm{min}, 4{ }^{\circ} \mathrm{C}\right)$ and centrifugation (11000 rpm, $3 \mathrm{~min}$ ), the cell lysate was transferred to a 96-well plate and the fluorescence was determined (excitation $\lambda=488 \mathrm{~nm}$; emission $\lambda=530 \mathrm{~nm}$ ) using a PolarSTAR OPTIMA microplate 
reader (BMG-Labtech, Cary, NC, USA). The fluorescence values obtained were normalized per $\mathrm{mg}$ of protein.

\subsection{Differential gene expression of tight junction proteins}

Cells were seeded in 6-well plates at a density of $4 \times 10^{4}$ cells per $\mathrm{cm}^{2}$, and 9 days after seeding they were treated with $\mathrm{As}(\mathrm{III})\left(1\right.$ and $\left.3 \mathrm{mg} \mathrm{L}^{-1}\right)$ and $\mathrm{As}(\mathrm{v})\left(5\right.$ and $8 \mathrm{mg} \mathrm{L}^{-1}$ ) for 4, 8 and $24 \mathrm{~h}$. RNA was extracted with the NucleoSpin RNA II kit (Macherey-Nagel, Düren, Germany). The RNA obtained was quantified spectroscopically using a NanoDrop ND-1000 (NanoDrop Technologies, Wilmington, NC, USA). Firststrand complementary DNA (cDNA) was obtained from $200 \mathrm{ng}$ of total RNA, using the Reverse Transcriptase Core Kit (Eurogentec Headquarters, Seraing, Belgium).

qPCR was performed using a LightCycler ${ }^{\circledR} 480$ real-time PCR instrument (Roche, Madrid, Spain). Reactions were carried out in a $10 \mu \mathrm{L}$ final volume containing $5 \mu \mathrm{L}$ of LightCycler ${ }^{\circledR} 480$ SYBR Green I Master Mix ( $2 \times$, Roche), $2.5 \mu \mathrm{L}$ of cDNA $\left(20 \mathrm{ng} \mu \mathrm{L}^{-1}\right)$, $1 \mu \mathrm{L}$ of each forward and reverse primer $(10 \mu \mathrm{M}$, Biolegio, Nijmegen, Netherlands) and nuclease-free water. The gene expression of proteins tight junction occludin (OCLN) and claudin 1 $(C L D N-1)$ was determined. The oligonucleotide sequences are shown in Table 1. PCR efficiency curves for each gene were calculated using 5 duplicate 2 -fold dilutions of cDNA.

\subsection{Patterns of distribution of zonula occludens 1 (ZO-1)}

Cells were seeded on round coverslips (12 mm diameter) placed on 24-well plates at a density of $4 \times 10^{4}$ cells per $\mathrm{cm}^{2}$. Nine days after seeding, the cells were exposed for $24 \mathrm{~h}$ to $\mathrm{As}(\mathrm{III})$ (1 and $3 \mathrm{mg} \mathrm{L}^{-1}$ ) and $\mathrm{As}(\mathrm{v})\left(5\right.$ and $8 \mathrm{mg} \mathrm{L}^{-1}$ ) prepared in MEMc. Then the monolayers were washed with PBS, fixed in $4 \%$ paraformaldehyde (v/v in PBS), permeabilized with $0.1 \%$ Triton X-100 (v/v in PBS) and blocked with $10 \%$ goat serum (Santa Cruz Biotechnology, Dallas, TX, USA).

For ZO-1 immunolocalization, cells were incubated overnight at $4{ }^{\circ} \mathrm{C}$ with rabbit polyclonal primary antibody anti-ZO1 (ab216880, Abcam, Cambridge, UK) diluted 1:200 in 2\% goat serum. For detection, the cells were incubated for $1 \mathrm{~h}$ at room temperature with goat anti-rabbit Alexa 488 (R37116, Invitrogen) diluted 1:200 in $2 \%$ goat serum, followed by incubation for $5 \mathrm{~min}$ with DAPI (4',6-diamidino-2-phenylindole, Sigma) diluted 1:400 in PBS. Finally, the samples were mounted in a ProLong ${ }^{\circledR}$ Antifade (Molecular Probe, Fisher Scientific) and examined under a Nikon Eclipse 90i fluorescence microscope.

\subsection{Evaluation of the cell monolayer permeability}

The assays were carried out in 6-well plates with polyester membrane inserts (24 mm diameter, pore size $0.4 \mu \mathrm{m}$, Transwell ${ }^{\circledR}$,
Corning, NY, USA). In this system the cells are seeded on the porous membrane of the insert that separates the well into two compartments: apical (upper) and basolateral (lower). The cells were seeded $\left(6.4 \times 10^{4}\right.$ cells per $\mathrm{cm}^{2}$ for Caco- 2 and $3 \times 10^{5}$ cells per $\mathrm{cm}^{2}$ for NCM460) on the apical side, with the addition of $1.5 \mathrm{~mL}$ of DMEMc or NCM-DMEMc to the apical chamber and $2 \mathrm{~mL}$ of DMEMc or NCM-DMEMc to the basolateral chamber. The cells were incubated at $37{ }^{\circ} \mathrm{C}, 5 \% \mathrm{CO}_{2}$ and $95 \%$ relative humidity, with a change of medium every 2-3 days. Eleven days after seeding, the cells were treated with $\operatorname{As}(\mathrm{III})(1$ and $\left.3 \mathrm{mg} \mathrm{L}^{-1}\right)$ and $\mathrm{As}(\mathrm{v})\left(5\right.$ and $\left.8 \mathrm{mg} \mathrm{L}^{-1}\right)$ for 8 and $24 \mathrm{~h}$.

The permeability of the monolayer was monitored by measuring the transport of Lucifer Yellow (LY) (Sigma) and fluorescein isothiocyanate (FITC)-dextran (average molecular weight 4000, Sigma). These fluorescent markers, LY $(100 \mu \mathrm{M})$ or FITCdextran $\left(1000 \mathrm{mg} \mathrm{L}^{-1}\right)$, were added to the apical compartment at the same time as the treatments with the As species. After the treatments, an aliquot from the basolateral compartment of each of the wells was used to quantify the LY or dextran contents at excitation/emission wavelengths of 485/520 nm, using a PolarSTAR OPTIMA fluorescence microplate reader.

\subsection{Statistical analysis}

All assays were performed at least in triplicate in independent cultures, and verified in a second experiment. The results were analysed statistically by one-factor analysis of variance (ANOVA) with Tukey HSD or Fisher LSD post hoc multiple comparison or using the Student $t$-test (SigmaPlot version 13.0). Differences were considered significant for $p<0.05$.

\section{Results}

\subsection{Inorganic As produces oxidative stress and a pro-inflammatory response in intestinal cells}

Fig. 1a and b present the percentage increase in formation of ROS and/or RNS by Caco-2 and NCM460 cells, respectively, treated with $\mathrm{As}(\mathrm{III})$ and $\mathrm{As}(\mathrm{v})$, with respect to the untreated control cells. In the Caco- 2 cells, formation of dichlorofluorescein (DCF, an indicator of ROS/RNS formation) took place after $4 \mathrm{~h}$ of treatment with $8 \mathrm{mg} \mathrm{L}^{-1}$ of $\mathrm{As}(\mathrm{v})(27 \%)$ and after $24 \mathrm{~h}$ of exposure to $3 \mathrm{mg} \mathrm{L^{-1 }}$ of As(III) (65\%). The NCM460 cells presented an increase in formation of DCF $24 \mathrm{~h}$ after treatment with As(III) at both concentrations (108-240\%). Exposure to As(v) of the NCM460 cells did not increase the formation of DCF in any of the treatments. These results indicate that

Table 1 Oligonucleotides employed in the study of the expression of tight junction proteins

\begin{tabular}{|c|c|c|c|c|}
\hline Gene & GenBank ID & Sequence $5^{\prime}-3^{\prime}$ & Amplicon size (bp) & Efficiency \\
\hline$G A D P H$ & NM_001289746.1 & $\begin{array}{l}\mathrm{F}: 5^{\prime} \text {-CATGAGAAGTATGACAACAGCCT-3' } \\
\mathrm{R}: 5^{\prime} \text {-AGTCCTTCCACGATACCAAAGT-3' }\end{array}$ & 113 & $1.95 \pm 0.06$ \\
\hline$O C L N$ & NM_021101.4 & $\begin{array}{l}\text { F: CCGGCGACAACATCGTGAC } \\
\text { R: CGGGTTGCTTGCAATGTGC }\end{array}$ & 136 & $2.07 \pm 0.06$ \\
\hline$C L D N-1$ & NM_002538.2 & $\begin{array}{l}\text { F: AAGAGTTGACAGTCCCATGGCATAC } \\
\text { R: ATCCACAGGCGAAGTTAATGGAAG }\end{array}$ & 133 & $1.93 \pm 0.05$ \\
\hline
\end{tabular}



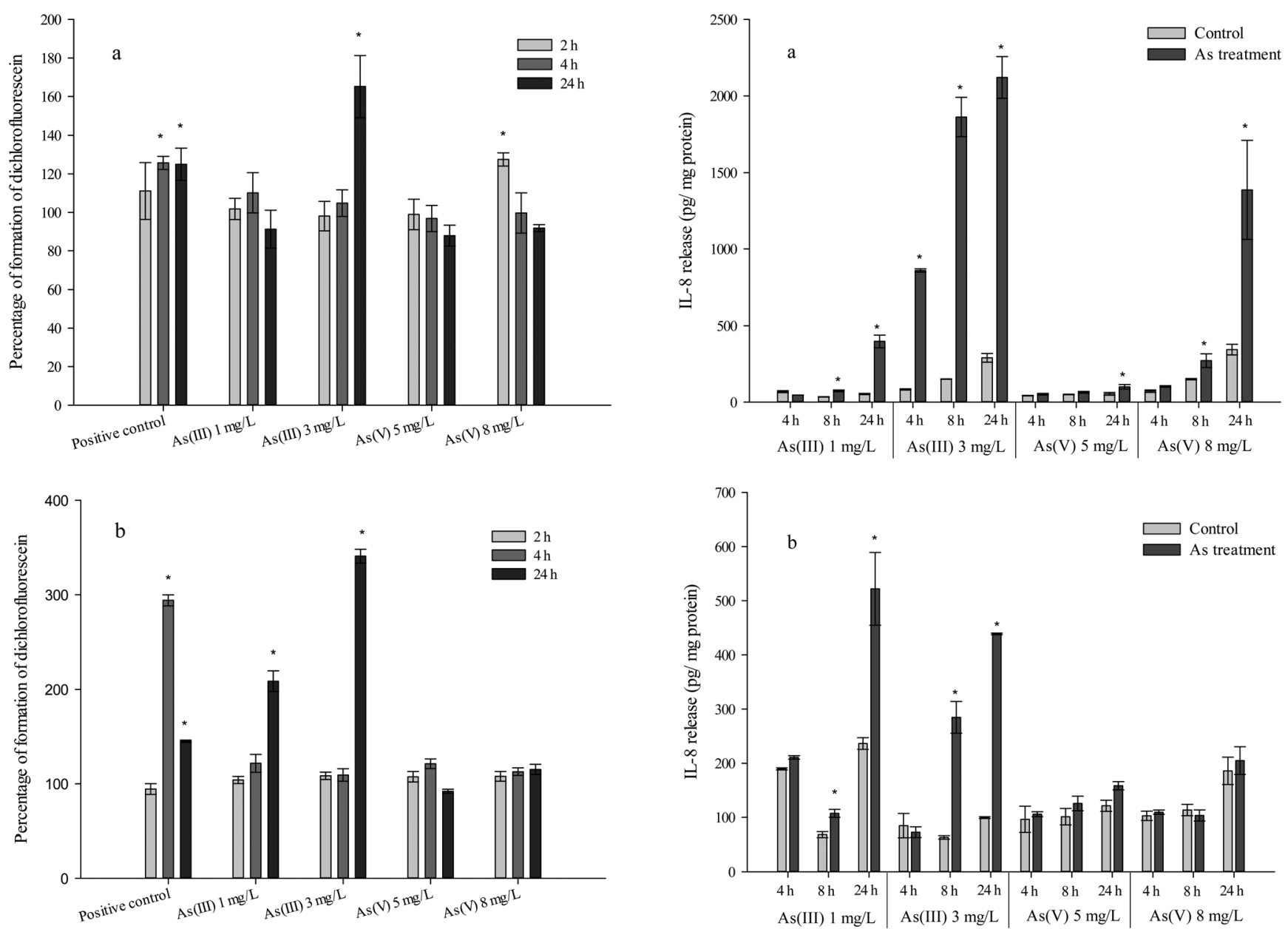

Fig. 1 Generation of ROS and/or RNS by Caco-2 cells (a) and NCM460 cells (b) exposed to inorganic As. Percentage of formation of dichlorofluorescein in cells exposed to As(III) ( 1 and $\left.3 \mathrm{mg} \mathrm{L}^{-1}\right)$ and As(v) $(5$ and $\left.8 \mathrm{mg} \mathrm{L}^{-1}\right)$ with respect to the control cells at various exposure times $(2,4$ and $24 \mathrm{~h})$. Values expressed as mean \pm SD $(n=3)$. Asterisks indicate statistically significant differences $(p<0.05)$ with respect to the control cells. The positive control used was tert-butyl hydroperoxide.

exposure to inorganic As, especially to As(III), produces oxidative stress in human intestinal cells.

With regard to the pro-inflammatory response, the levels of the cytokines IL-2, IL-6 and TNF $\alpha$ did not change substantially after the exposure to inorganic As (data not shown), however, changes in the IL-8 release are observed. Fig. $2 a$ and $b$ show the levels of release of IL-8 to the medium of the Caco- 2 and NCM460 cells, respectively, after the treatment with As(III) and As(v). In the Caco-2 cells, all the treatments with $\mathrm{As}(\mathrm{III})$ increased the release of IL-8 (115-1135\%), with the exception of $1 \mathrm{mg} \mathrm{L}^{-1}$ of As(III) after $4 \mathrm{~h}$ of exposure. The treatments with $\operatorname{As}(\mathrm{v})$ were able to increase the release of IL-8 after $8 \mathrm{~h}$ and $24 \mathrm{~h}$ (28-303\%), although the pro-inflammatory response was less than the response triggered by As(III). For the NCM460 cells, the treatments with As(III) produced an increase in the release of IL-8 after $8 \mathrm{~h}$ and $24 \mathrm{~h}$ of exposure (57-353\%); however, As(v) did not generate a pro-inflammatory response in any of the treatments. In view of the results, we can conclude that

Fig. 2 Pro-inflammatory response in Caco- 2 cells (a) and NCM460 cells (b) exposed to inorganic As. Release of the pro-inflammatory cytokine IL- 8 to the culture medium in the control cells and cells exposed to As(III) (1 and $\left.3 \mathrm{mg} \mathrm{L}^{-1}\right)$ and $\mathrm{As}(\mathrm{v})\left(5\right.$ and $\left.8 \mathrm{mg} \mathrm{L}^{-1}\right)$. Values expressed as pg per $\mathrm{mg}$ protein (mean $\pm \mathrm{SD}, n=3$ ). Asterisks indicate statistically significant differences $(p<0.05)$ with respect to the control cells.

exposure to inorganic As, especially As(III), generates a proinflammatory response in human colonic cells.

\subsection{Inorganic As alters the expression and distribution of} tight junction proteins and produces an increase in permeability

The permeability of the intestinal epithelium depends mainly on the tight junctions formed by a number of proteins whose distribution is crucial for maintaining the structure and functionality of the epithelium. ${ }^{19}$ In the present work, modification of this protein network was observed as a result of exposure to inorganic As.

Expression of tight junction proteins is only affected in Caco-2. There was a downregulation of $C L D N-1$ in all As treatments except for cells treated with As(v) $5 \mathrm{mg} \mathrm{L}^{-1}$ (Table 2). Moreover, a redistribution of ZO-1 has been observed for both cell lines after As exposure. The morphology of the monolayers generated by Caco-2 and NCM460 cells was different (Fig. 3). The Caco-2 cells formed a well-defined monolayer with a 
distribution of the ZO-1 protein that gave it a cobblestone-like appearance (Fig. 3A). In contrast, the NCM460 cells had a looser structure, with the tight junctions less well defined, showing multilayered growth in some sections (Fig. 3E). The result of these morphological differences was that the effect of the inorganic forms of As on the morphology was more evident in the Caco-2 cell line (Fig. 3A-D). In general, the treatments altered the distribution of the ZO-1 protein, and there was a greater intensity of fluorescence in the cytoplasm of the treated cells. Furthermore, the cell monolayer lost its cobblestone-like morphology.

With regard to the permeability, the behaviour of the two types of cells was different, as was to be expected in view of the morphological differences just described. The Caco-2 cells presented a transepithelial electrical resistance (TEER) that varied between 250 and $380 \mathrm{~m} \Omega \mathrm{cm}^{-2}$, whereas the NCM460 cells presented a TEER similar to the resistance measured in an insert without cells. This was reflected in the transport of the fluorescent markers assayed (LY and dextran), which were used to evaluate the paracellular permeability. The mean of the $P_{\text {app }}$ of LY in control Caco-2 cells was $2 \times 10^{-7} \mathrm{~cm} \mathrm{~s}^{-1}$; whereas the coefficient of permeability in NCM460 was much greater, even for the dextran $\left(1.40 \pm 0.03 \times 10^{-6} \mathrm{~cm} \mathrm{~s}^{-1}\right)$. For this reason, to assess the effect of the treatment with inorganic As on the permeability of the monolayers formed by Caco-2, the LY transport was evaluated; whereas for NCM460, the permeability was measured by analysing the dextran transport.

Fig. 4 presents the transport of $\mathrm{LY}$ in the Caco-2 cells treated with inorganic As and in the control cells. Treatment with $\mathrm{As}(\mathrm{v})$ did not modify transport of LY with respect to the control cells, whereas the cells treated with As(III) showed greater transport in the treatments of $24 \mathrm{~h}$, and the treatment at the highest concentration $\left(3 \mathrm{mg} \mathrm{L}^{-1}\right)$ was the one that generated the greatest increase in permeability (14 times). The transport of dextran in NCM460 was also affected by the inorganic As treatments. For these cells both forms of inorganic As increased the permeability (Fig. 5). These results show that inorganic As, especially As(III), produces a redistribution of tight junction proteins and an increase in permeability in human intestinal cells.

\section{Discussion}

Studies on the toxic effects of As on an intestinal level are scarce. It has been shown in vitro that acute exposure to trivalent forms of As [arsenite, $\operatorname{As}(\mathrm{III})$, monomethylarsonous acid, MMA(III) and dimethylarsinous acid, DMA(III)] generates oxidative stress (an increase in ROS and/or RNS, a reduction of intracellular GSH contents, up-regulation of stress proteins and metallothioneins, a reduction in catalase and GSH peroxidase activity and lipid peroxidation) and an increase in secretion of pro-inflammatory cytokines (TNF- $\alpha$ and IL-8) in Caco-2 cells. ${ }^{9,11}$ In the present study it was seen that $\operatorname{As}($ III) can also generate a stress situation and a pro-inflammatory response in non-transformed human colon epithelial cells (NCM460). Moreover, arsenate [As(v)], the major 

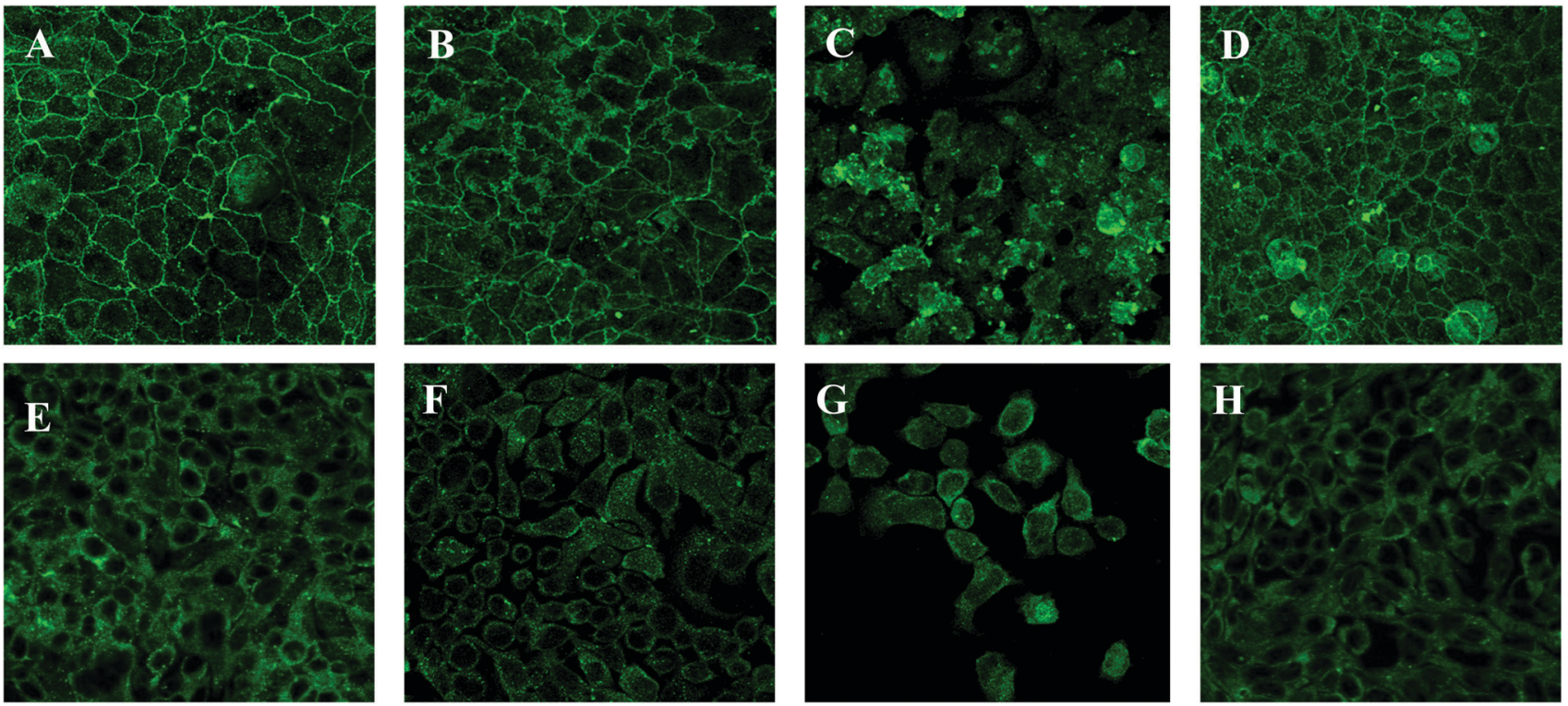

Fig. 3 Immunodetection of ZO-1 in monolayers of Caco-2 cells (A-D) and NCM460 cells (E-H). (A and E) Represent untreated control cells; (B and F) cells treated with $\mathrm{As}(\mathrm{III})\left(1 \mathrm{mg} \mathrm{L}^{-1}\right)$ for $24 \mathrm{~h}$; $(\mathrm{C}$ and $\mathrm{G})$ cells treated with $\mathrm{As}(\mathrm{III})\left(3 \mathrm{mg} \mathrm{L}^{-1}\right)$ for $24 \mathrm{~h}$; $(\mathrm{D}$ and $\mathrm{H})$ cells treated with $\mathrm{As}(\mathrm{V})\left(8 \mathrm{mg} \mathrm{L^{-1 }}\right)$ for $24 \mathrm{~h}$. Amplification $40 \times$

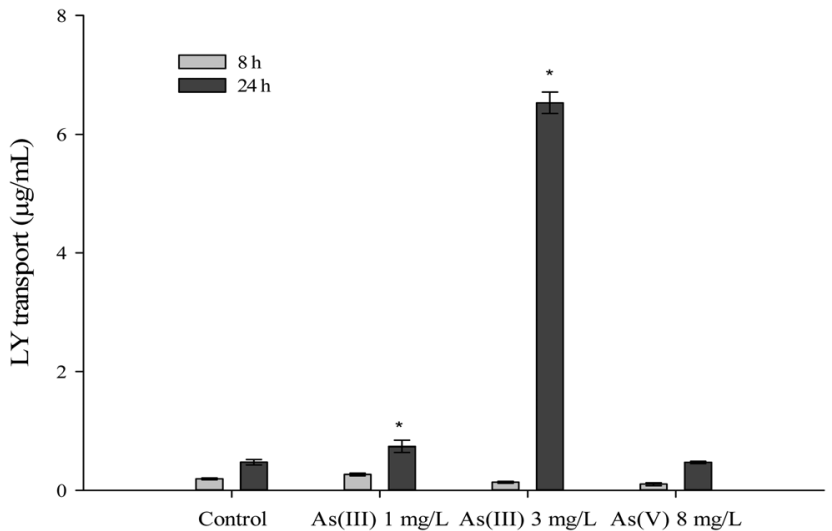

Fig. 4 Effect of inorganic As on the permeability of Caco-2 cells. Transport of Lucifer Yellow (LY) across the cell monolayer in the control cells and cells treated with $\mathrm{As}(\mathrm{III})\left(1 \mathrm{mg} \mathrm{L}^{-1}\right.$ and $\left.3 \mathrm{mg} \mathrm{L}^{-1}\right)$ and $\mathrm{As}(\mathrm{v})\left(8 \mathrm{mg} \mathrm{L}^{-1}\right)$ for 8 and $24 \mathrm{~h}$. Values expressed as $\mu \mathrm{g} \mathrm{LY}$ per $\mathrm{mL}$ (mean $\pm \mathrm{SD}, n=3$ ). Asterisks indicate statistically significant differences $(p<0.05)$ with respect to the control cells.

form of As in water, rice, vegetables and some kinds of algae, also generates these cytotoxic effects in colonic cells.

The pathogenesis and evolution of various gastrointestinal inflammatory diseases such as colorectal cancer and chronic inflammatory bowel diseases (IBD: Crohn's disease or ulcerative colitis) are associated with oxidative stress. ${ }^{20,21}$ Recent studies have demonstrated that ROS derived from mitochondria act as signal transduction molecules that cause an increase in the expression of pro-inflammatory cytokines through various pathways. ${ }^{22}$ The link between pro-inflammatory cytokines and the immunopathogenesis of IBD is also well documented, where they drive and regulate multiple aspects of intestinal inflammation. ${ }^{23}$

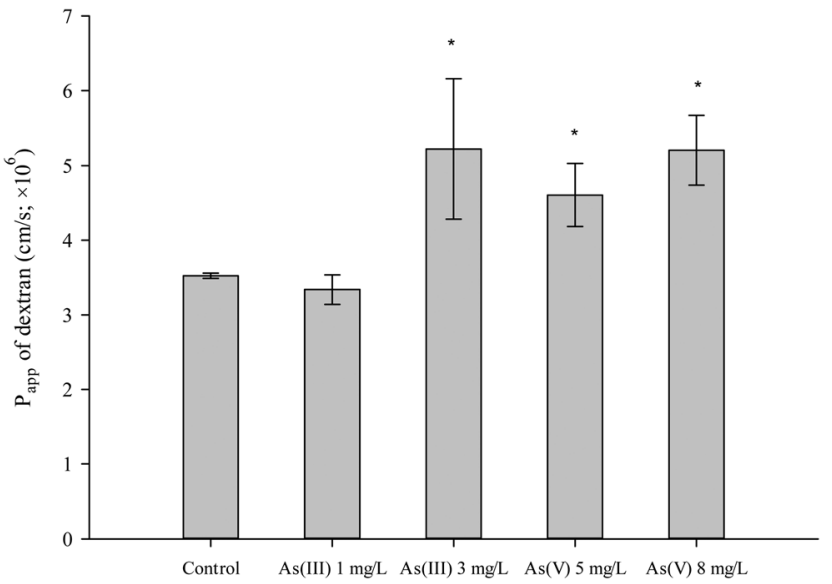

Fig. 5 Effect of inorganic As on the permeability of NCM460 cells. Apparent permeability coefficient $\left(P_{\text {app }}\right)$ of dextran across the cell monolayer in the control cells and cells treated with $\mathrm{As}(\mathrm{III})\left(1 \mathrm{mg} \mathrm{L}^{-1}\right.$ and $\left.3 \mathrm{mg} \mathrm{L}^{-1}\right)$ and $\mathrm{As}(\mathrm{v})\left(5 \mathrm{mg} \mathrm{L}^{-1}\right.$ and $\left.8 \mathrm{mg} \mathrm{L}^{-1}\right)$ for $24 \mathrm{~h}$. Values expressed as $\mathrm{cm} \mathrm{s}^{-1}$ (mean $\pm \mathrm{SD}, n=3$ ). Asterisks indicate statistically significant differences $(p<0.05)$ with respect to the control cells.

The pro-inflammatory and pro-oxidant response detected after exposure to inorganic As may be responsible for the structural and functional modifications seen in the monolayers formed by these two types of cells. The treatments with As(III) and $\mathrm{As}(\mathrm{v})$ produced a change in the morphology of the epithelial layers, especially notable in Caco-2 (Fig. 3). It is possible to see a change in the distribution of $Z O-1$ and a reduction in the expression of $C L D N-1$ (Table 2), tight junction proteins that are involved in maintaining the structure of the epithelium.

Previous studies have shown that the disassembly of tight junctions caused by cytokines is due to the fact that cytokines act by modifying the expression and/or localization of the 
proteins that form these junctions, ${ }^{24}$ as happened in the present study. It has also been demonstrated that ROS can produce cytoskeleton rearrangements and redistribution and disappearance of tight junction proteins, claudin- 5 and occludin, in the blood brain barrier. ${ }^{25}$ The effect of inorganic As on the components of tight junctions was shown previously in a mouse trachea epithelial cell model. ${ }^{26}$ Those authors showed that epithelial cells of the respiratory pathway exposed to As(III) (0.60-290 $\left.\mu \mathrm{g} \mathrm{L}^{-1}\right)$ exhibited altered patterns of localization of some tight junction proteins. The data obtained in the present study show for the first time that this toxic effect can also be produced at the intestinal level in cases of acute exposure to $\mathrm{As}(\mathrm{III})$ and $\mathrm{As}(\mathrm{v})$.

The effect of inorganic As on tight junctions may be responsible for the increase in paracellular transport (Fig. 4 and 5), especially apparent in the treatments with $\mathrm{As}(\mathrm{III})$. It has been evidenced that the disassembly of tight junctions causes an increase in the paracellular permeability. ${ }^{24}$ This increase in permeability is associated with numerous intestinal disorders, especially the development of autoimmune and inflammatory diseases. $^{3}$ In fact, in animal models of IBD the increase in epithelial paracellular permeability precedes chronic inflammation of the intestinal mucosa. ${ }^{27}$ It must be noted that the intestinal epithelium provides a layer with selective permeability that prevents the passage of pathogens and toxic compounds. Therefore, loss of this barrier leads to deregulated, non-specific intestinal permeability, with the result that harmful microorganisms or substances can come into contact with the immune system present in the lamina propia. ${ }^{27}$ This contact with the intestinal immune system may induce an exacerbated immune response and the appearance of chronic processes. This entire cascade of events, leading to inflammatory processes in the intestine, has been demonstrated in the case of exposure to external agents such as alcohol; ${ }^{28}$ however, they have not been confirmed in the presence of toxic trace elements.

This study demonstrates that exposure to the inorganic forms of As, principally to As(III), has an effect on intestinal permeability, causing a loss of intestinal barrier function, which, if it continues, as commented earlier, could trigger an intestinal inflammatory process. Moreover, given that there is an important paracellular component in the transport of inorganic As across the epithelium, ${ }^{29,30}$ an increase in paracellular permeability may lead to greater transport of these inorganic forms across the epithelium, possibly increasing the quantity of As that reaches systemic circulation. There is a need for in vivo studies to confirm the effects of acute and subchronic exposure to inorganic forms of As administered orally on the gastrointestinal tract, and the possible systemic repercussions.

\section{Abbreviations}

$\begin{array}{ll}\text { As } & \text { Arsenic } \\ \text { As(III) } & \text { Arsenite } \\ \text { As(v) } & \text { Arsenate } \\ \text { CLDN-1 } & \text { Claudin 1 } \\ \text { DCF } & \text { Dichlorofluorescein }\end{array}$

$\begin{array}{ll}\text { DHCF-DA } & \text { Dihydrochlorofluorescein diacetate } \\ \text { DMA(III) } & \text { Dimethylarsinious acid } \\ \text { DMEM } & \text { Dulbecco's Modified Eagle Medium } \\ \text { DMEMc } & \text { DMEM supplemented for Caco-2 cells } \\ \text { EDTA } & \text { Ethylenediaminetetraacetic acid } \\ \text { FBS } & \text { Fetal bovine serum } \\ \text { FITC } & \text { Fluorescein isothiocyanate } \\ \text { HEPES } & \text { N-2-Hydroxyethylpiperazine- } N^{\prime}-2- \\ & \text { ethanesulfonic acid } \\ \text { IBD } & \text { Chronic inflammatory bowel diseases } \\ \text { IL } & \text { Interleukin } \\ \text { LY } & \text { Lucifer yellow } \\ \text { MAPK } & \text { Mitogen-activated protein kinases } \\ \text { MMA(III) } & \text { Monomethylarsonous acid } \\ \text { MEM } & \text { Minimum Essential Medium Eagle with Earle's } \\ & \text { salts } \\ \text { MEMc } & \text { MEM supplemented with sodium pyruvate, } \\ & \text { penicillin, streptomycin and amphotericin B } \\ \text { NCM-DMEMc } & \text { DMEM supplemented for NCM460 cells } \\ \text { OCLN } & \text { Occludin } \\ \text { PBS } & \text { Phosphate-buffered saline } \\ \text { RNS } & \text { Reactive nitrogen species } \\ \text { ROS } & \text { Reactive oxygen species } \\ \text { TEER } & \text { Transepithelial electric resistance } \\ \text { TNF } \alpha & \text { Tumor necrosis factor alpha } \\ \text { ZO-1 } & \text { Zonula occludens 1 } \\ & \end{array}$

\section{Conflicts of interest}

There are no conflicts to declare.

\section{Acknowledgements}

This work was supported by the Spanish Ministry of Economy and Competitiveness (AGL2015-68920-R), for which the authors are deeply indebted. Gabriela de Matuoka e Chiocchetti received a fellowship from the Brazilian Government (CAPESBEX1086/14-6) to carry out this study.

\section{References}

1 IARC, Monographs on the Evaluation of Carcinogenic Risks to Humans. Overall Evaluations of Carcinogenicity: an Updating of IARC Monographs, International Agency for Cancer Research, 2004, vol. 84, p. 39.

2 Y.-S. Hong, K.-H. Song and J.-Y. Chung, Health effects of chronic arsenic exposure, J. Prev. Med. Public Health, 2014, 47, 245-252.

3 K. R. Groschwitz and S. P. Hogan, Intestinal barrier function: molecular regulation and disease pathogenesis, J. Allergy Clin. Immunol., 2009, 124, 3-20.

4 T. Suzuki and H. Hara, Quercetin enhances intestinal barrier function through the assembly of zonula [corrected] occludens-2, occludin, and claudin-1 and the expression of claudin-4 in Caco-2 cells, J. Nutr., 2009, 139, 965-974. 
5 M. Camilleri, K. Lasch and W. Zhou, Irritable bowel syndrome: methods, mechanisms, and pathophysiology. The confluence of increased permeability, inflammation, and pain in irritable bowel syndrome, Am. J. Physiol.: Gastrointest. Liver Physiol., 2012, 303, G775-G785.

6 T. Kovacs, L. Kun, M. Schmelczer, L. Wagner, J. C. Davin and J. Nagy, Do intestinal hyperpermeability and the related food antigens play a role in the progression of IgA nephropathy? I. Study of intestinal permeability, Am. J. Nephrol., 1996, 16, 500-505.

7 P. Brun, I. Castagliuolo, V. Di Leo, A. Buda, M. Pinzani, G. Palu and D. Martines, Increased intestinal permeability in obese mice: new evidence in the pathogenesis of nonalcoholic steatohepatitis, Am. J. Physiol.: Gastrointest. Liver Physiol., 2007, 292, G518-E525.

8 M. Nouri, A. Bredberg, B. Weström and S. Lavasani, Intestinal barrier dysfunction develops at the onset of experimental autoimmune encephalomyelitis, and can be induced by adoptive transfer of auto-reactive T cells, PLOS One, 2014, 9, e106335.

9 M. Calatayud, V. Devesa and D. Velez, Differential toxicity and gene expression in Caco-2 cells exposed to arsenic species, Toxicol. Lett., 2013, 218, 70-80.

10 M. Calatayud, J. V. Gimeno-Alcañiz, D. Vélez and V. Devesa, Trivalent arsenic species induce changes in expression and levels of proinflammatory cytokines in intestinal epithelial cells, Toxicol. Lett., 2014, 224, 40-46.

11 M. Calatayud, J. V. Gimeno-Alcañiz, V. Devesa and D. Vélez, Proinflammatory effect of trivalent arsenical species in a co-culture of Caco-2 cells and peripheral blood mononuclear cells, Arch. Toxicol., 2015, 89, 555-564.

12 G. M. Chiocchetti, D. Vélez and V. Devesa, Effect of subchronic exposure to inorganic arsenic on the structure and function of the intestinal epithelium, Toxicol. Lett., 2018, 286, 80-88.

13 R. A. Rocha, D. Vélez and V. Devesa, In vitro evaluation of intestinal fluoride absorption using different cell models, Toxicol. Lett., 2012, 210, 311-317.

14 M. Calatayud, S. S. Farias, G. S. de Paredes, M. Olivera, N. Á. Carreras, M. C. Giménez, V. Devesa and D. Vélez, Arsenic exposure of child populations in Northern Argentina, Sci. Total Environ, 2019, 669, 1-6.

15 D. N. G. Mazumder, A. Ghosh, K. K. Majumdar, N. Ghosh, C. Saha and R. N. G. Mazumder, Arsenic contamination of ground water and its health impact on population of district of nadia, west bengal, India, Indian J. Community Med., 2010, 35, 331-338.

16 C. Almela, S. Algora, V. Benito, M. J. Clemente, V. Devesa, M. A. Suner, D. Velez and R. Montoro, Heavy metal, total arsenic, and inorganic arsenic contents of algae food products, J. Agric. Food Chem., 2002, 50, 918-923.

17 J. J. Sloth and K. Julshamn, Survey of total and inorganic arsenic content in blue mussels (Mytilus edulis L.) from
Norwegian fiords: revelation of unusual high levels of inorganic arsenic, J. Agric. Food Chem., 2008, 56, 1269-1273.

18 M. R. Islam, M. Jahiruddin and S. Islam, Assessment of arsenic in the water-soil-plant systems in Gangetic floodplains of Bangladesh, Asian J. Plant Sci., 2004, 3, 489-493.

19 T. Suzuki, Regulation of intestinal epithelial permeability by tight junctions, Cell. Mol. Life Sci., 2013, 70, 631-659.

20 A. Bhattacharyya, R. Chattopadhyay, S. Mitra and S. E. Crowe, Oxidative stress: an essential factor in the pathogenesis of gastrointestinal mucosal diseases, Physiol. Rev., 2014, 94, 329-354.

21 A. Roessner, D. Kuester, P. Malfertheiner and R. SchneiderStock, Oxidative stress in ulcerative colitis-associated carcinogenesis, Pathol., Res. Pract., 2008, 204, 511-524.

22 E. Naik and V. M. Dixit, Mitochondrial reactive oxygen species drive proinflammatory cytokine production, J. Exp. Med., 2011, 208, 417-420.

23 Q. Guan and J. Zhang, Recent Advances: The Imbalance of Cytokines in the Pathogenesis of Inflammatory Bowel Disease, Mediators Inflammation, 2017, 2017, 4810258.

24 C. T. Capaldo and A. Nusrat, Cytokine regulation of tight junctions, Biochim. Biophys. Acta, 2009, 1788, 864-871.

25 G. Schreibelt, G. Kooij, A. Reijerkerk, R. van Doorn, S. I. Gringhuis, S. van der Pol, B. B. Weksler, I. A. Romero, P.-O. Couraud, J. Piontek, I. E. Blasig, C. D. Dijkstra, E. Ronken and H. E. de Vries, Reactive oxygen species alter brain endothelial tight junction dynamics via RhoA, PI3 kinase, and PKB signaling, FASEB J., 2007, 21, 3666-3676.

26 C. L. Sherwood, A. E. Liguori, C. E. Olsen, R. C. Lantz, J. L. Burgess and S. Boitano, Arsenic compromises conducting airway epithelial barrier properties in primary mouse and immortalized human cell cultures, PLoS One, 2013, 8, e82970.

27 L. Pastorelli, C. De Salvo, J. R. Mercado, M. Vecchi and T. T. Pizarro, Central role of the gut epithelial barrier in the pathogenesis of chronic intestinal inflammation: lessons learned from animal models and human genetics, Front. Immunol., 2013, 4, 280.

28 A. Keshavarzian, A. Farhadi, C. B. Forsyth, J. Rangan, S. Jakate, M. Shaikh, A. Banan and J. Z. Fields, Evidence that chronic alcohol exposure promotes intestinal oxidative stress, intestinal hyperpermeability and endotoxemia prior to development of alcoholic steatohepatitis in rats, J. Hepatol., 2009, 50, 538-547.

29 M. Calatayud, J. Gimeno, D. Velez, V. Devesa and R. Montoro, Characterization of the intestinal absorption of arsenate, monomethylarsonic acid, and dimethylarsinic acid using the Caco-2 cell line, Chem. Res. Toxicol., 2010, 23, 547-556.

30 M. Calatayud, V. Devesa, R. Montoro and D. Velez, In vitro study of intestinal transport of arsenite, monomethylarsonous acid, and dimethylarsinous acid by Caco-2 cell line, Toxicol. Lett., 2011, 204, 127-133. 